\title{
A bibliometric evaluation of European Union research of the respiratory system from 1987-1998
}

\author{
F. García-Río*, S. Serrano*, A. Dorgham*, R. Alvarez-Sala*, A. Ruiz Peña*, J.M. Pino*, \\ J.L. Alvarez-Sala ${ }^{\#}$, J. Villamor*
}

A bibliometric evaluation of European Union research of the respiratory system from 1987-1998. F. García-Río, S. Serrano, A. Dorgham, R. Alvarez-Sala, A. Ruiz Peña, J.M. Pino, J.L. Alvarez-Sala, J. Villamor. C) ERS Journals Ltd 2001.

ABSTRACT: This study analyses the evolution of the bibliometric indicators of productivity and repercussion of European Union (EU) research into the respiratory system during the period from 1987-1998, describing the geographical distribution.

Using MedLine, a selection was made of those articles by EU authors published between 1987-1998 in 38 respiratory system journals (classification from the Institute for Scientific Information). The journals, country of origin, number of articles and the relation to socioeconomic data, productivity index, visibility index, expected impact factor (EIF) and relative impact factor (RIF) were all analysed.

The number of $\mathrm{EU}$ publications in respiratory system journals experienced an exponential increase, going from 606 articles $(14.3 \%$ of world production) in 1987 , to $2,325(33.2 \%)$ in 1998. During this same period, the EIF increased from 1,258 to 2,111. The greatest gross productivities were those of the UK, France, Italy and Germany, although when corrected for number of inhabitants, Sweden, the Netherlands, Belgium and Denmark headed the list. The countries with the greatest mean EIF were the Netherlands, the UK, Spain and Belgium.

In conclusion, productivity and repercussions of European Union research of the respiratory system experienced an important increase during this period. Eur Respir J 2001; 17: 1175-1180.

\begin{abstract}
*Servicios de Neumología, Hospital Universitario La Paz and " Hospital
\end{abstract} Clínico San Carlos, Madrid, Spain.

Correspondence: F. García-Río Alfredo Marqueríe 11 , izqda, $1^{\circ} \mathrm{A}$ 28029 Madrid

Spain.

Fax: 34915771309

Keywords: Bibliometry respiratory scientific information statistics

Received: August 102000 Accepted after revision January 18 2001
The importance of research in the development and progress of countries is currently a widely accepted fact. However, the economic resources that this activity requires grows at a rate much lower than that of the economic resources made available by most nations. There exists, therefore, an evident interest in developing new scientific indicators, capable of facilitating the analysis of the results of research activities together with the planning and management of the research and the most efficient use possible of the existing limited economic resources [1].

Through the use of different indicators, bibliometry allows for aspects of importance to be quantified, such as production, circulation, obsolescence, consumption and repercussions of scientific activity $[1-5]$. In spite of its known limitations and frequent abuses [6,7], bibliometric analysis constitutes a procedure of great utility in evaluating health sciences. In the last few years, bibliometric studies have proliferated, seeking to provide data on the situation of world research or that of certain countries [8-11]. Most of these analyses supply complementary data, with a utility similar to that of macroeconomic indicators, whose overall vision makes it possible to evaluate the evolution of a scientific production in particular, determining its quality and providing reasons to reflect upon the interventions that could possibly be developed [1].

Europe has not been excluded from this tendency towards a growing use of bibliometric indicators. To date, some studies on European scientific production in biomedicine and life sciences are available [12-14], as well as those of certain medical disciplines; among these rheumatology [15], cardiology [16] or cancer [17] stand out.

Despite the evident sanitary implications in relation to health and well-being and the considerable socioeconomic repercussions of the area of the respiratory system, there exists little specific information about European scientific activity in this field. Except for a bibliometric study of publications about tobacco habit [18] and some bibliometric analyses by a Spanish respiratory system journal [19-21], there is hardly any information available about the participation of European research groups in international respiratory journals.

The objectives of this study were to analyse, by means of the bibliometric indicators of production and repercussion, the contribution of European Union (EU) authors to research in the respiratory area from 1987-1998. It was also the intention to determine the participation of the different countries in creating these published articles. 


\section{Material and methods}

\section{Data collection}

A search was performed of the articles published between 1987-1998 included in MedLine through the PubMed project (www.ncbi.nlm.nih.gov/PubMed/ medline.html) [22]. The delimitation of the respiratory field was made according to the journals, adhering to the classification of the journals into subareas by the "Journal Citation Reports" (JCR) of the "Science Citation Index" [23]. As such, all those journals included in the "Respiratory System" section of the JCR from 1987-1998 [24], which were also contained in the Medline database, were selected. The complete list of the 38 journals analysed is shown in table 1 .

The search strategy was centered on two fields: journals (where the ISSN or international standard serial numbers of all the respiratory area journals were entered in accordance with the aforementioned list) and place of work of the authors. To limit the search to those documents in which the first signing institution belonged to the EU, in the "Affiliation" field, the following terms were entered: "Austria", "Belgium", "Denmark", "Finland", "France", "Germany", "Greece", "Ireland", "Italy", "Luxembourg", "Netherlands",

Table 1. - List of journals analysed in this study

American Journal of Respiratory and Critical Care Medicine American Journal of Respiratory Cell and Molecular Biology American Review of Respiratory Disease

Annals of Thoracic Surgery

Applied Cardiopulmonary Pathophysiology

British Journal of Diseases of the Chest

Bulletin Europeen de Physiopathologie Respiratoire

Clinics in Chest Medicine

Chest

European Journal of Cardio-Thoracic Surgery

European Journal of Respiratory Diseases

European Respiratory Journal

Experimental Lung Research

Heart \& Lung

International Journal of Tuberculosis and Lung Disease

Journal of Aerosol Medicine

Journal of Asthma

Journal of Cardiothoracic and Vascular Anesthesia

Journal of Cardiovascular Pharmacology

Journal of Heart and Lung Transplantation

Journal of Heart Transplantation

Journal of Thoracic and Cardiovascular Surgery

Laryngoscope

Lung

Lung Cancer

Pediatric Pulmonology

Pulmonary Pharmacology

Pulmonary Pharmacology and Therapeutics

Respiration

Respiration Physiology

Respiration Medicine

Revue des Maladies Respiratoires

Sarcoidosis

Sarcoidosis, Vasculitis and Diffuse Lung Diseases

Thoracic and Cardiovascular Surgeon

Thorax

Tubercle

Tubercle and Lung Disease
"Portugal", "Spain", "Sweden", "United Kingdom", "England", "Wales", "Scotland" and "Northern-Ireland", separated by the Boolean operator "or". The articles from England, Wales, Scotland and Northern Ireland were grouped under the denomination UK. To compare the EU research with other major areas in the world, the term "Japan" was also included in the search. Through a manual review procedure of the totality of the articles selected, the origins were verified and the titles of the journals, years of publication and countries of place of work of the first authors were compiled.

\section{Indicators analysed}

The production and repercussion of scientific activity in the respiratory field in the EU were studied, evaluating these through biomedical publications (table 2). Production was evaluated using the number of documents published and the productivity index or logarithm of the number of articles published. In addition, a statistical weighting was carried out on the scientific production of each EU country according to socioeconomic parameters. In doing so, the gross domestic product (GDP) was used as well as the population of each country from 1987-1998, which were obtained through the EUROSTAT database [25]. These indices were expressed as number of articles published per 1 billion ECUs of GDP and number of articles per 100,000 inhabitants.

The repercussion of the articles published was evaluated by use of the expected visibility index, the expected impact factor and the relative impact factor (RIF). Given that the impact factor of a journal represents the citations received by the average article of said journal in a set period of time, this can be used as an indicator of the number of citations expected for an article published in that journal [26]. The expected visibility index was calculated as the logarithm of the sum total of the number of expected citations of the documents analysed. The expected impact factor corresponds to the quotient between the number of expected citations and the number of documents. The relative impact factor was considered to be the quotient between the expected impact factor of a country and the mean expected impact factor of the EU. An RIF of $>1$ indicates that that country published articles in journals with a greater impact factor than that of the European average.

\section{Results}

A total of 19,562 documents published by EU authors between 1987 and 1998 were compiled. Figure 1 presents the annual evolution of the number of articles published. This grew from 606 documents in 1987 to 1,742 in 1992 and 2,325 in 1998. The production of the EU in the respiratory area during the entire study period represented $28.6 \%$ of the world total. Said per cent also increased significantly throughout these years, going from $14.3 \%$ in 
Table 2. - Definition of bibliometric terms employed

\begin{tabular}{|c|c|}
\hline Term & Definition \\
\hline Productivity index & Logarithm of the number of documents published. \\
\hline Citation index & $\begin{array}{l}\text { Alphabetical list, by first author, of items cited in references } \\
\text { of a source article. }\end{array}$ \\
\hline Impact factor of a journal & $\begin{array}{l}\text { Average number of times articles published in the } 2 \\
\text { previous years are cited in the current year. }\end{array}$ \\
\hline Expected citations in a journal & $\begin{array}{l}\text { Number of articles published by a magazine in a year multiplied } \\
\text { by the impact factor of the magazine for that year. }\end{array}$ \\
\hline Total expected citation & Sum of the expected citations in all journals. \\
\hline Expected visibility index & Logarithm of the total expected citations. \\
\hline Expected impact factor & $\begin{array}{l}\text { Quotient between the total of expected citations and the } \\
\text { number of documents. }\end{array}$ \\
\hline Relative impact factor & $\begin{array}{l}\text { Quotient between the expected impact factor of a country and } \\
\text { the mean expected impact factor of the European Union. }\end{array}$ \\
\hline Cited half-life & $\begin{array}{l}\text { Number of journal publication years going back from the current } \\
\text { year which account for } 50 \% \text { of the total citations received } \\
\text { by the cited journal in the current year }\end{array}$ \\
\hline Immediacy index & $\begin{array}{l}\text { Average number of times current articles in a specific } \\
\text { journal were cited during the year they were published }\end{array}$ \\
\hline Self-citation rate & $\begin{array}{l}\text { Self-citations (when an article in a journal cites another article published } \\
\text { in the same journal) expressed as a percentage of all citations }\end{array}$ \\
\hline
\end{tabular}

1987 to $29.0 \%$ in 1992 and $33.2 \%$ in 1998 (fig. 1) the year in which the greatest production was reached.

Table 3 shows the distribution of the articles depending on the journals in which they were published. A nucleus made up of six journals containing $57.4 \%$ of the articles published was identified: European Respiratory Journal and its predecessors with 2,333 documents, Journal of Cardiovascular Pharmacology with 2,094 articles, American Journal of Respiratory and Critical Care Medicine and American Review of Respiratory Disease with 1,944 publications, Chest with 1,677 publications, Thorax with 1,595 publications and Annals of Thoracic Surgery with 1,579 articles.

The bibliometric indicators of production, adjusted according to socioeconomic data, confirm the increase in scientific activity between 1987 and 1998 (fig. 2). The productivity index went from 2.78 in 1987 to 3.37 in 1998. Likewise, the number of articles per 100,000

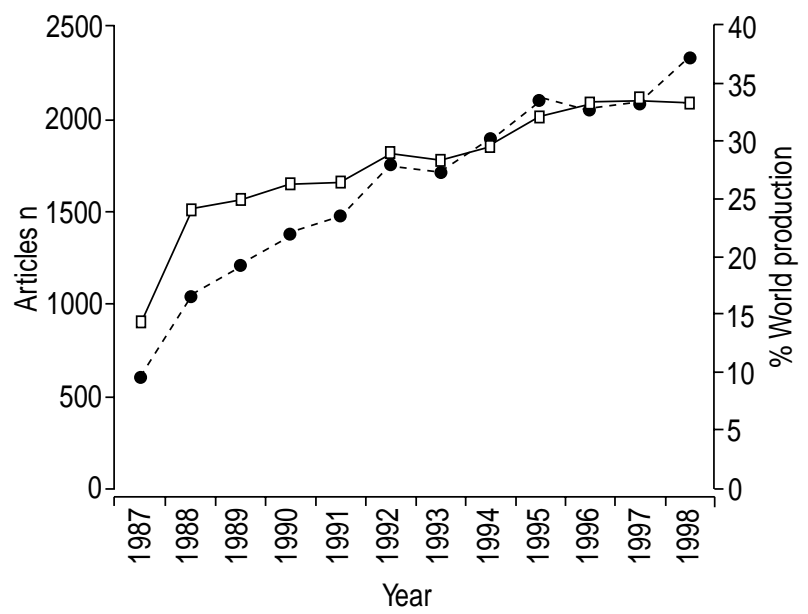

Fig. 1. - Evolution of the number of articles (O) and per cent with respect to the worldwide total of articles ( $\square$ ) published by authors of the European Union in the respiratory system area. inhabitants went from 0.172 in 1987 to 0.634 in 1998 , with a mean of 0.452 articles per 100,000 inhabitants. The productivity index of Japan went from 1.64 in 1987 to 2.63 in 1998 and the number of articles per 100,000 inhabitants went from 0.036 in 1987 to 0.340 in 1998.

The repercussion of the scientific production of the EU as a whole in the respiratory field also increased throughout the years of the study. The expected visibility index was 2.880 in 1987, 3.434 in 1992 and 3.691 in 1998. Despite the increase in the number of articles published, the expected impact factor also experienced considerable growth, going from 1.258 in 1987 to 1.573 in 1992 and 2.111 in 1998 (fig. 3). In contrast, the expected visibility index for Japan was 1.770 in 1987 and 2.965 in 1998 and the expected impact factor was 1.339 in 1987 and 2.150 in 1998 .

In decreasing order, the 10 countries with a greater mean productivity between 1987 and 1998 were the UK $(26.8 \%$ of the total EU production), France $(20.6 \%)$, Italy $(11.1 \%)$, Germany $(10.1 \%)$, the Netherlands $(8.5 \%)$, Sweden $(5.2 \%)$, Belgium $(4.8 \%)$, Spain (4.7\%), Denmark (2.4\%) and Austria (2.0\%). Although the UK and France continued to be the top producers throughout the years of the study, German production increased from $2.6 \%$ in 1987 to $15.3 \%$ in 1998 , placing third in production in said year. Spain also experienced an important increase, representing $2.6 \%$ of EU production in 1987 and $5.5 \%$ in 1998 , which resulted in an ascent from eighth to sixth place in the ranking of producer countries.

Nevertheless, the list of countries with greater production is altered when corrected for the gross number of articles published depending on socioeconomic data. According to the number of inhabitants, the order of the most productive EU member states is headed by Sweden, followed by the Netherlands, Belgium, Denmark, the UK, Finland, France, Austria, Ireland and Italy. The greatest increases in this indicator between 1987 and 1998 
Table 3.-Distribution of the articles published between 1987 and 1998 in the journals of the "Respiratory System" section of the "Journal Citation Reports"

\begin{tabular}{|c|c|}
\hline Journal & Articles \\
\hline European Respiratory Journal* & 2333 \\
\hline Journal of Cardiovascular Pharmacology & 2094 \\
\hline $\begin{array}{l}\text { American Journal of Respiratory and Critical } \\
\text { Care Medicine }\end{array}$ & 1944 \\
\hline Chest & 1677 \\
\hline Thorax & 1595 \\
\hline Annals of Thoracic Surgery & 1579 \\
\hline Revue des Maladies Respiratoires & 1313 \\
\hline European Journal of Cardio-Thoracic Surgery & 1245 \\
\hline Journal of Thoracic and Cardiovascular Surgery & 863 \\
\hline Respiratory Medicine & 646 \\
\hline Thoracic and Cardiovascular Sur & 477 \\
\hline Respi & 414 \\
\hline Journal of Heart and Lung Transplantation ${ }^{+}$ & 393 \\
\hline Pediatric Pulmonology & 339 \\
\hline Laryn & 334 \\
\hline $\begin{array}{l}\text { Journal of Cardiothoracic and Vascular } \\
\text { Anesthesia }\end{array}$ & 305 \\
\hline Respiration Physiology & 274 \\
\hline $\begin{array}{l}\text { American Journal of Respiratory Cell and } \\
\text { Molecular Biology }\end{array}$ & 271 \\
\hline $\begin{array}{l}\text { International Journal of Tuberculosis and Lung } \\
\text { Disease }^{\S}\end{array}$ & 259 \\
\hline Pulmonary Pharmacology and Therapeutics ${ }^{f}$ & 258 \\
\hline Lung & 244 \\
\hline Sarcoidosis, Vascular and Diffuse Lung Disease** & 209 \\
\hline Lung Cancer & 173 \\
\hline Experimental Lung Research & 106 \\
\hline Journal of Asthma & 78 \\
\hline Journal of Aerosol Medicine & 77 \\
\hline Clinics in Chest Medicine & 26 \\
\hline Hear & 25 \\
\hline Applied Cardiopulmonary Pathophysiology & 11 \\
\hline
\end{tabular}

*: Includes the Bulletin Europeen de Physiopathologie Respiratoire and the European Journal of Respiratory Diseases; \#: includes the American Review of Respiratory Disease; ?: includes the British Journal of Diseases of the Chest; ${ }^{+}$: includes the Journal of Heart Transplantation; ${ }^{\S}$ : includes Tubercle and Tubercle and Lung Disease, ${ }^{f}$ : includes Pulmonary Pharmacology; **: includes Sarcoidosis.

were those of Germany, Spain, the Netherlands and Italy. In 1998, the highest producers with respect to GDP were, also in decreasing order, the Netherlands, Sweden, Belgium, Finland, the UK, France, Denmark, Italy, Greece and Spain.

Of the years analysed in total, the highest expected impact factor was that of the Netherlands (1.908), followed by the UK (1.903), Spain (1.858) and Belgium (1.841). Also placing above the EU average were Luxembourg (1.831), Italy (1.798) and Ireland (1.717). The countries with a greatest increase in repercussion between 1987 and 1998 were Italy, which went from eighth place to first, and Spain, ascending from twelfth place to fourth.

\section{Discussion}

The results of this study reveal that scientific production of the EU in respiratory system journals increased from $1987-1998$, both in absolute value as

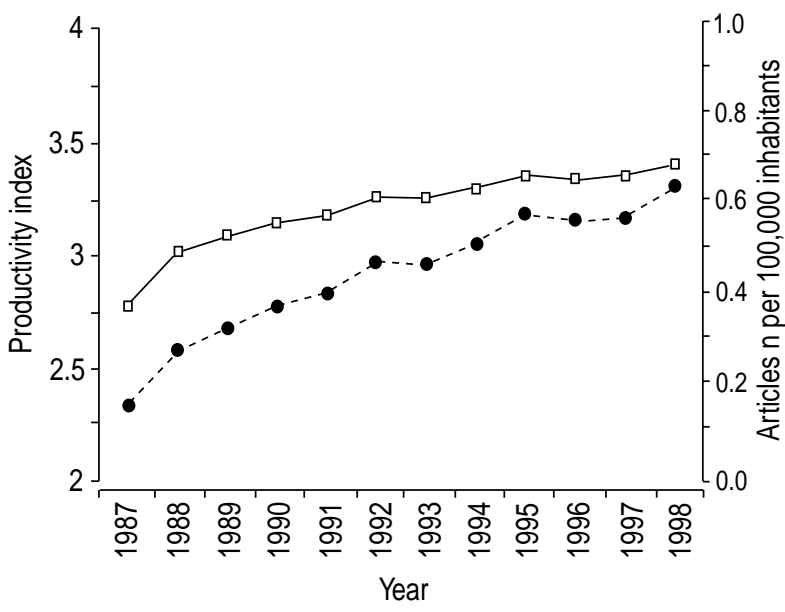

Fig. 2. - Annual evolution of the main bibliometric indicators for production of the European Union in the respiratory system field. $\square$ : productivity index; 0 : articles published per 100,00 inhabitants.

well as in per cent of world production. At the same time, the articles have been published each year in journals with greater impact factors, promoting the repercussion of European production.

There exist various methodological aspects related to the choice of the data source and the selection criteria that deserve a preliminary consideration. The MedLine database was chosen as it is the most accessible and utilized biomedical medium. Moreover, MedLine was recently demonstrated to be suitable for bibliometric studies of scientific production in biomedicine of a member state of the EU [27]. It is necessary to keep in mind that according to the selection system used, this study did not analyse articles published in collaboration with non-EU institutions in which a European researcher did not appear as the main author. Nor were publications in general medicine journals or in respiratory journals that were not included in the Journal Citation Reports

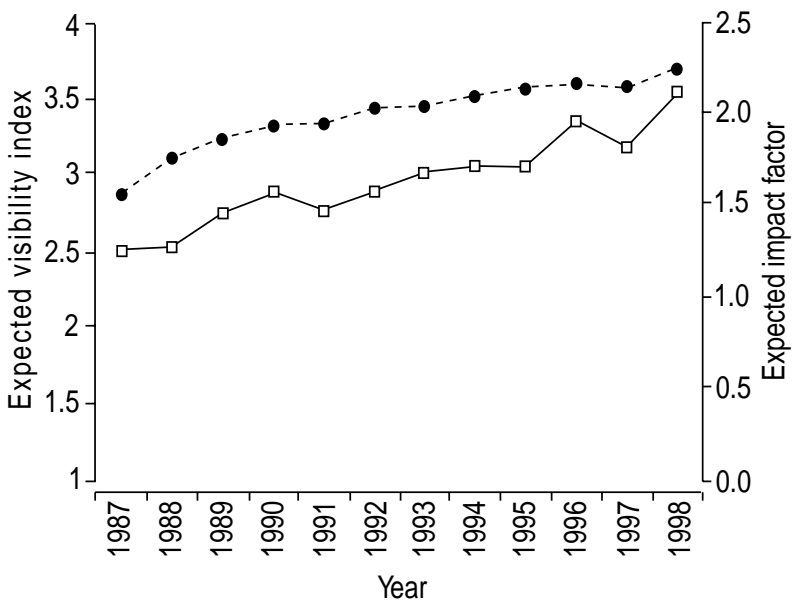

Fig. 3. - Annual evolution of the main bibliometric indicators for repercussion of scientific activity of the European Union in the respiratory system field. : expected visibility index; $\square$ : expected impact factor. 
or on MedLine considered. As for the biases originating in the classification of the journals into areas by topic by the Journal Citation Reports, a high number of documents published by cardiovascular surgeons and cardiologists in the respiratory area [28] has recently been reported. This fact proves the inadequate definition of this area due to the inclusion of cardiological periodic publications, and even those of cardiovascular surgery, and the scarce presence of pneumological journals [21].

During the period of study, EU production in the respiratory field was higher than Japanese productivity. However, it is difficult to establish a comparison of present results with previous data found in the literature, given that, to the authors' knowledge, specific studies do not exist about scientific production in the respiratory field by authors of the EU. In addition, the comparison with other topic areas gives rise to problems due to the difference in size and, therefore, in growth rate. For instance, the production of the EU in the respiratory area is only slightly less than and even similar to that reached in general biomedicine or oncology. From 1986-1989, the participation of the EU in world respiratory production $(20.7 \%)$ was less than in biomedicine (28.9\%) [12]. These percentages evened out between 1990-1993 (27.5 and $29.3 \%$, respectively) [13], and the respiratory participation decreased again in 1995 (32.1\% and $37.5 \%$, respectively) [15]. The production of the EU in cancer in 1995 was $36.5 \%$ of the world total [17], a quantity relatively similar to that obtained in the present study that same year $(32.1 \%)$. There are no more recent data available to be able to establish comparisons for the last few years.

The increase in the quantity of published respiratory articles by EU authors was accompanied by an increase in repercussion. Due to the limitations of the impact factor in comparing topic areas [7], the contrast of the repercussion reached in other topic areas by European authors is questionable. In any event, and as an example, the expected impact factor (EIF) reached by the respiratory articles published in 1995 was 1.7 , while that obtained by rheumatology articles was 2.0 [15] and 2.4 by those of oncology [17]. If these data are compared with the maximum impact factor of the publications in each topic area that year, the relative impact factor for respiratory would be $0.267,0.155$ for oncology and 0.276 for rheumatology. Therefore, it can be inferred that the repercussion of the European research in the respiratory area is similar to or more than that reached in other areas of clinical medicine. Nevertheless, EU mean expected impact factor for the study period was slightly lower than other major scientific areas in the world, such as Japan. Probably, this difference could be attributed to the higher dispersion of EU production and to regional differences. In fact, in 1998, the UK, Spain, the Netherlands, Italy and Ireland had higher EIFs than Japan.

The distribution of the scientific productivity in the EU in the respiratory field is relatively similar to that reported in other disciplines. The greatest producers in biomedicine in 1995 were the UK (27.5\%), Germany $(17.5 \%)$, France $(14.9 \%)$, Italy $(9.7 \%)$, the Netherlands
(6.5\%), Spain $(5.6 \%)$ and Sweden $(5.4 \%)$ [15]. In that same year, the articles published by the EU on oncology were from the UK (19.1\%), Italy $(18.7 \%)$, Germany $(14.3 \%)$, France $(13.7 \%)$, the Netherlands $(10.1 \%)$, Sweden $(7.1 \%)$, Spain $(2.9 \%)$, Denmark (2.6\%), Belgium (2.4\%) and Austria (2.3\%) [17]. Lastly, in rheumatology, a similar distribution was reported: UK $(29.4 \%)$, France $(17.4 \%)$, Germany $(11.5 \%)$, Italy $(10.8 \%)$, the Netherlands $(7.5 \%)$, Spain $(5.7 \%)$ and Sweden (4\%) [15]. The majority of the studies coincide in that during this period the activity of the middle producers increased, while those countries with high productivity (the UK and France) maintained their leadership [16, 29].

However, the studies available on the production of the EU in biomedicine [12, 13], rheumatology [15] and oncology [17] coincide in highlighting that the countries with the greatest productivity, in relation to socioeconomic indicators, are the Scandinavian and small-sized central European countries. The reason for which small countries reach such high adjusted scientific production is by no means defined but could be attributed to a better utilization of resources, a larger percentage of investment in research and development, the prevalence of certain diseases that justifies a greater volume of research in said medium, or the lack of domestic journals in that country's language. It is also possible that some characteristics of geographical distribution of productivity are due to northern/southern differences in fluency in English. Finally, Austria, Finland and Sweden joined the European Community (EC) in 1995. Because it is generally accepted that scientific political changes need a long period to produce results, it is improbable that joining the EC can influence the scientific production of these countries in the following $3 \mathrm{yrs}$. In fact, evolution of their production and repercussion indices have not changed over these last years.

As for the geographical distribution of the repercussion indicators, those countries whose scientific production of the respiratory system reached a greater expected impact factor from 1987-1998 were, in decreasing order, the Netherlands, the UK, Spain, Belgium, Luxembourg, Italy, Ireland, Finland, Sweden, Austria, Greece, Germany, France, Denmark and Portugal. This pattern of distribution of the repercussion of the scientific activity in the EU basically coincides with that described in other medical disciplines, such as oncology [17], cardiology [16] or rheumatology [15]. Also standing out in these three fields as countries with the greatest repercussion are the Netherlands and the UK. In any event, the important role played by Spain, Belgium, Ireland, Finland or Sweden confirms, as happens in other scientific fields [16], the relevant contribution of the average producers in the bibliometric repercussion indicators of a community.

In conclusion, the scientific production in the respiratory system in the European Union has been shown to have experienced a considerable increase from 1987-98, in quantity as well as in repercussion of said activity. Likewise, those countries with the most relevant contribution in productivity and repercussion have been identified. Lastly, no attempt 
should be made at relating the described changes in the European Union as a whole, or in any one of its member states, with political or social events, in spite of their being seemingly temporarily associated. It is also a known fact that in order for actions taken based on scientific activity to reach their objectives, a long period of time, even longer than that of the present study, is necessary.

\section{References}

1. Moed HF, de Bruin RE, Nederhof AJ, van Raan AFJ, Tijssen RJW. State of the art of bibliometric macroindicators. An overview of demand and supply. Commission of the European Community. Luxemburg, European Community Official Publications Office, 1992.

2. López Piñero JM, Terrada ML. Los indicadores bibliométricos y la evaluación de la actividad médico-científica. (I) Usos y abusos de la bibliometría. Med Clin (Barc) 1992; 98: 64-68.

3. López Piñeiro JM, Terrada ML. Los indicadores bibliométricos y la evaluación de la actividad médicocientífica (III). Los indicadores de producción, circulación y dispersión, consumo de la información y repercusión. Med Clin (Barc) 1992; 98: 142-148.

4. Garfield E. How can impact factor be improved? BMJ 1996; 313: $411-413$

5. Similowski T, Derenne JP. Bibliométrie des périodiques biomédicaux. Rev Mal Respir 1995; 12: 543 - 550.

6. Camí J. Impactolatría: diagnóstico y tratamiento. Med Clin (Barc) 1997; 109: 515-524.

7. García-Río F. Estrategias para una búsqueda bibliográfica eficiente. Bibliometría. Valoración crítica. Arch Bronconeumol 1999; 35: Suppl. 1, 27-30.

8. Schubert A, Glänzel W, Braun T. Scientometric datafile. A comprehensive set of indicators on 2,649 journals and 96 countries in all major science fields and subfields 1981-1985. Scientometrics 1989; 16: 3 478.

9. Braun T, Glänzel W, Grupp H. The scientometric weight of 50 nations in 27 science areas, 1989-93. Part II. Life Sciences. Scientometrics 1995; 34: $207-237$.

10. Yamazaki S. Ranking Japan's life science research. Nature 1994; 372: 125-126.

11. May RM. The Scientific Wealth of Nations. Science 1997; 275: $793-796$

12. Camí J, Fernández MT, Gómez I. La producción científica española a través del Science Citation Index (1986-1989). Med Clin (Barc) 1993; 101: 721-731.

13. Camí J, Zulueta MA, Fernández MT, Bordons M, Gómez I. Producción científica española en biomedicina y ciencias de la salud durante el periódo 1990 - 1993 (Science Citation Index y Social Science
Citation Index) y comparación con el período 1986-1989. Med Clin (Barc) 1997; 109: 481 -496.

14. Hefler L, Tempfer C, Kainz C. Geography of biomedical publications in the European Union, 1990 - 98. Lancet 1999; 353: 1856.

15. Mela GS, Cimmino MA. An overview of rheumatological research in the European Union. Ann Rheum Dis 1998; 57: 643-647.

16. de Jong JW, Schaper W. The international rank order of clinical cardiology. Eur Heart $J$ 1996; 17: 35-42.

17. Mela GS, Cimmino MA, Ugolini D. Impact assessment of oncology research in the European Union. Eur J Cancer 1999; 35: 1182-1186.

18. Garcia-Lopez JA. Bibliometric analysis of Spanish scientific publications on tobacco use during the period 1970-1996. Eur J Epidemiol 1999; 15: 23-28.

19. García-Río F, Alvarez-Sala R, Prados C, Alvarez-Sala JL. Cuál es la difusión internacional real de Archivos de Bronconeumología? Arch Bronconeumol 1996; 32: 551 .

20. García-Río F, Dorgham A, Serrano S, et al. Evolución de los indicadores bibliométrico s de producción y consumo de Archivos de Bronconeumología durante los últimos 20 años. Arch Bronconeumol 1997; 33: 20 26.

21. García-Río F, Serrano S, Alvaro D, et al. Estimación de los indicadores bibliométricos de repercusión de Archivos de Bronconeumologia. Arch Bronconeumol 1998; 34: $531-535$.

22. García Díaz F. Búsqueda de bibliografía médica a través de Internet. El proyecto PubMed. Med Clin (Barc) 1999; 113: 58-62.

23. Gervás JJ, Pérez Fernández MM, García Sagredo P. Science Citation Index: posibilidades y utilización. Med Clin (Barc) 1990; 95: 582-588.

24. Science Citation Index. Journal Citation Reports. Philadelphia, Institute for Scientific Information Inc., $1987-1998$

25. Statistical Office of the European Communities (Eurostat), Brussels, Eurostat, ECSC-ECEAEC, 1999.

26. Garfield E. How ISI selects journals for coverage: quantitative and qualitative considerations. Curr Contents 1990; 22: 5-13.

27. Pestaña A. El MedLine como fuente de información bibliométrica de la producción española en biomedicina y ciencias médicas. Comparación con el Science Citation Index. Med Clin (Barc) 1997; 109: $506-511$.

28. García-Río F, Alvarez-Sala R, Gómez Mendieta MA, et al. Evolución de la producción científica española en revistas internacionales de sistema respiratorio de 1987 a 1998. Med Clin (Barc) 2000; 115: 287-293.

29. Shahla M, Vahaeghe V, Hedeshi AR, Friedman G, Vincent JL. European participation in major intensive care journals. Int Care Med 1995; 21: 7-10. 